\title{
Altruism and Internal Locus of Control as Determinants of the Intention to Participate in Crowdfunding: The Mediating Role of Trust
}

\section{Yusimi Rodriguez-Ricardo', Maria Sicilia² and Manuela López ${ }^{3}$}

${ }^{1}$ University of Murcia, Faculty of Economics and Business, Murcia, Spain, yusimi.rodriguez@um.es

${ }^{2}$ University of Murcia, Faculty of Economics and Business, Murcia, Spain, sicilia@um.es

${ }^{3}$ University of Murcia, Faculty of Economics and Business, Murcia, Spain, manuela.lopez@um.es

Received 5 May 2017; received in revised form 2 August 2018; accepted 26 September 2018

\begin{abstract}
This paper aims to analyze the determinants of participation in crowdfunding. As any individual may participate in a crowdfunding project, the study analyzes the general audience as potential contributors. This study develops and tests a model that includes personal determinants-internal locus of control and altruism-of the intention to participate in crowdfunding. Trust in crowdfunding is proposed as a mediator in the model. Data from 245 individuals were gathered via an online panel to test the hypotheses. Altruism and internal locus of control are found to enhance trust in crowdfunding, which, in turn, influences individuals' intention to participate. Companies or entrepreneurs that are currently using or expecting to use crowdfunding to finance their project should develop marketing strategies that focus on enhancing trust towards their projects. Likewise, they should target individuals who are more altruistic and with higher levels of internal locus of control.
\end{abstract}

Keywords: Crowdfunding, Trust, Locus of control, Altruism, Participation in crowdfunding 


\section{Introduction}

The phenomenon of crowdfunding has grown significantly in recent years due to the expansion of the Internet. Crowdfunding aims to collect money by drawing on small contributions [12], [64], [63]. It has emerged as an important alternative source of finance for various types of projects, enabling fundraising from a large number of individuals via online platforms [45], [54]. Initially crowdfunding was mainly used to finance artistic projects [1], but it has quickly extended to other sectors, including innovative projects from technology to knowledge-based start-ups [44].

According to a sector report [59], there are more than 1250 active crowdfunding platforms (CFPs) around the world. Kickstarter.com, one of the most popular CFPs, has grown since its launch in 2009 to over $\$ 2$ billion in 2016, funding more than 100,000 projects with the pledges of more than 10 million people [51]. Likewise, a recent study conducted by Crowdfunding Universe [83] established that crowdfunding in Spain raised more than $€ 113$ million in 2016, reflecting an increase of $116 \%$ compared with 2015 when it raised just $€ 52$ million.

Any individual can be a potential contributor to crowdfunding projects [57]. Therefore, crowdfunding can be considered as per any other consumption activity in which a contribution has to be made by the consumer and some value is obtained in reward. According to [2], rewards to participate in crowdfunding may be extrinsic (financial) or intrinsic (nonfinancial). Individuals may decide to participate in a project in exchange for some intrinsic and/or extrinsic reward, and the motivations to participate in crowdfunding are derived from the rewards obtained from that participation.

The question that arises when thinking about individuals as potential contributors is who potential supporters are. In line with recent research that highlights the greater importance of intrinsic compared to extrinsic motivations in crowdfunding participation [2], [36], [54], we analyze altruism and internal locus of control (LOC) as personal traits that may enhance intrinsic motivations to participate in this activity. Altruism has been selected in this study because it may be one of the personal traits that intrinsically motivate individuals to participate in crowdfunding projects. In fact, [61] confirmed that many contributions in crowdfunding have altruistic motivations. Internal LOC has been selected because individuals' beliefs about the effects of their actions in terms of the results of certain events (that is, internal LOC) [46] could affect their intention to participate in crowdfunding projects. A higher probability of participating is expected among more altruistic individuals, and among those who have high levels of internal LOC. In addition, trust has been revealed as a key factor in crowdfunding [28], so it is also included in the current study. Since the relations between personality traits and behavior can be better explained by investigating the role of mediating variables [19], trust in crowdfunding is incorporated as a mediator in the model.

To the best of our knowledge, no research to date has described the general audience as potential supporters of crowdfunding. By general audience, we are here referring to the range of consumers regardless of their previous experience with crowdfunding-that is, including both individuals who have already participated in crowdfunding projects and those who have no previous experience in supporting crowdfunding projects, but who could be potential crowdfunders in the future. In this study, we focus on this segment.

As a consequence, this study will shed light on the determinants that increase propensity to participate in crowdfunding as a regular consumption activity. Since we analyze the general audience, our results could provide initial knowledge of individuals' behavior related to this emerging phenomenon. As [79] stated, obtaining new supporters is critical for crowdfunding. Therefore, the findings of this study could help entrepreneurs, companies, and other interested parties in utilizing crowdfunding effectively, extending the scope of their crowdfunding campaigns to a larger audience, as well as addressing their efforts to those who may be more prone to participate.

Following previous research on crowdfunding, in this study we analyze altruism and internal LOC as personal traits that may influence individuals' intention to participate in crowdfunding projects. In the following section, a set of hypotheses is developed in which trust acts as a mediator of the proposed model. The managerial and theoretical implications of the study are discussed at the end of the paper.

\section{Theoretical Background and Hypotheses}

This section aims to define the crowdfunding concept as well as to explain the motivations and determinants to participate in crowdfunding. Then, Self-Determinantion Theory is used as theoretical background to stablish the proposed hypotheses.

\subsection{Crowdfunding}

Strictly speaking, crowdfunding is not a recent invention. For instance, Mozart and Beethoven financed concerts and the publication of new music manuscripts via advanced subscriptions from interested members of the public; likewise, part of the construction of the Statue of Liberty in New York was funded by small donations from the American 
people [44]. Crowdfunding is defined as the efforts made by entrepreneurial individuals and groups to fund their ventures by relying on small contributions from a relatively large number of individuals via the Internet, without standard financial intermediaries [63].

The concept of crowdfunding is derived from the broader concept of crowdsourcing, which describes the process of outsourcing a task to a large, often anonymous number of individuals-the crowd-drawing on their assets, knowledge, or expertise, and using them to obtain ideas, feedback, or solutions to a corporate activity [44]. Crowdfunding has also been related to the concept of co-creation [79], since individuals' participation can take various forms, such as contributing ideas or testing early prototypes [55]. In addition, some CFPs have developed online communities for entrepreneurs and supporters to share ideas with each other to support their coproduction behavior [87].

Existing literature in crowdfunding has been inspired in some ways by previous literature in crowdsourcing, which has analyzed the phenomenon [29], [34] and determinants of participation in crowdsourcing activities [72]. The crowdsourcing phenomenon has significantly changed relations between firms and consumers [52]. The primary motivations for consumers to participate in crowdsourcing are intrinsic (for the fun of it) [52]. Determinants of participation in crowdsourcing activities could include recognition for work done, or the satisfaction of pursuing common goals [24]. Likewise, people may decide to participate in these activities to receive certain career-related benefits [74], to acquire new knowledge, or to share expertise with others [38].

Although crowdfunding is a relatively new phenomenon, related literature is emerging quickly from multidisciplinary approaches [66]. The first empirical studies on crowdfunding were qualitative, and initial market data were analyzed and enhanced with findings from interviews [37], [44]. Quantitative studies began to emerge following the growth of CFPs as intermediaries, making data available from crowdfunding project transactions [65]. Existing research has also shed some light on determinants of crowdfunding success [1], [11], [45], [63]; motivations to create crowdfunding projects [12], [38]; and motivations and determinants of participation in crowdfunding [2], [37], [79]. The main results concerning determinants of crowdfunding project creation, and participation in such projects, are summarized in Table 1.

Table 1: Previous research on crowdfunding

\begin{tabular}{|c|c|c|c|}
\hline Study & Method (sample) & Determinants/motivations & Main results \\
\hline \multicolumn{4}{|c|}{ Motivations to create crowdfunding projects } \\
\hline [12] & $\begin{array}{l}\text { Quantitative } \\
\text { (51 projects, } 69 \\
\text { entrepreneurs) }\end{array}$ & $\begin{array}{l}\text {-Raise funds } \\
\text {-Get public attention } \\
\text {-Obtain feedback on the product/service } \\
\text { offered }\end{array}$ & $\begin{array}{l}\text { Capital-seekers are } \\
\text { motivated by the collection } \\
\text { of funds, the attainment of } \\
\text { public attention, and } \\
\text { obtaining feedback }\end{array}$ \\
\hline [37] & $\begin{array}{l}\text { Qualitative (interviews } \\
\text { with project creators) }\end{array}$ & $\begin{array}{l}\text {-Raise funds } \\
\text {-Receive validation of the project } \\
\text {-Connect with funders } \\
\text {-Replicate successful } \\
\text { experiences of others } \\
\text {-Expand awareness of work through social } \\
\text { media }\end{array}$ & $\begin{array}{l}\text { Capital-seekers are } \\
\text { motivated by securing } \\
\text { funding and supporters by } \\
\text { consuming products and } \\
\text { experiences }\end{array}$ \\
\hline \multicolumn{4}{|c|}{ Motivations and determinants of participation in crowdfunding projects } \\
\hline [2] & $\begin{array}{l}\text { Quantitative } \\
\text { (transactions data from } \\
\text { Kiva crowdfunding } \\
\text { platform) }\end{array}$ & $\begin{array}{l}\text { DV: Time needed to fund a microloan } \\
\text { IV: Language characteristics in project } \\
\text { presentation: } \\
\text {-Profit language (positive effect) } \\
\text {-Risk taking language (positive effect) } \\
\text { - Human interest language (negative effect) } \\
\text {-Overall intrinsic language (negative effect) } \\
\text {-Overall extrinsic language (positive effect) }\end{array}$ & $\begin{array}{l}\text { Supporters respond } \\
\text { positively to narratives } \\
\text { highlighting the venture as } \\
\text { an opportunity to help } \\
\text { others, and less positively } \\
\text { when the narrative is framed } \\
\text { as a business opportunity }\end{array}$ \\
\hline [36] & $\begin{array}{l}\text { Qualitative (interviews } \\
\text { with project creators) }\end{array}$ & $\begin{array}{l}\text {-Collect rewards } \\
\text {-Distrust of creators' use of funds } \\
\text {-Help others } \\
\text {-Be part of a community } \\
\text {-Support a cause }\end{array}$ & $\begin{array}{l}\text { Crowdfunding involves } \\
\text { preparing and testing } \\
\text { campaign material, } \\
\text { marketing the project and } \\
\text { executing the project goals }\end{array}$ \\
\hline [53] & $\begin{array}{l}\text { Quantitative } \\
\text { (projects data from } \\
\text { Kickstarter } \\
\text { crowdfunding platform) }\end{array}$ & $\begin{array}{l}\text { DV: Backer added support } \\
\text { IV: Past backer support (negative effect) }\end{array}$ & $\begin{array}{l}\text { Supporters do not contribute } \\
\text { to projects that have } \\
\text { received a lot of support, } \\
\text { assuming that the } \\
\text { necessary funding will be } \\
\text { provided }\end{array}$ \\
\hline
\end{tabular}




\begin{tabular}{|c|c|c|c|}
\hline \multicolumn{4}{|c|}{ Table 1: continuation } \\
\hline$[21]$ & $\begin{array}{l}\text { Quantitative } \\
\text { (survey of } 151 \\
\text { investors, Symbiad } \\
\text { crowdfunding platform) }\end{array}$ & $\begin{array}{l}\text { DV: Intention to invest as } 10 \% / 30 \% \text { equity } \\
\text { IV: Financial motivations }\end{array}$ & $\begin{array}{l}\text { Financial motivations are } \\
\text { significant for both equity- } \\
\text { and rewards-based } \\
\text { crowdfunding projects }\end{array}$ \\
\hline [37] & $\begin{array}{l}\text { Qualitative (interviews } \\
\text { with project creators) }\end{array}$ & $\begin{array}{l}\text {-Seek rewards } \\
\text {-Support creators and causes } \\
\text { - Engage and contribute to a trusting and } \\
\text { creative community }\end{array}$ & $\begin{array}{l}\text { Supporters are motivated by } \\
\text { a desire to collect rewards, } \\
\text { help others, support causes, } \\
\text { and be part of a community }\end{array}$ \\
\hline [79] & $\begin{array}{l}\text { Quantitative (survey of } \\
544 \text { investors) }\end{array}$ & $\begin{array}{l}\text { Motivations: } \\
\text {-Interest } \\
\text {-Playfulness } \\
\text {-Philanthropy } \\
\text {-Reward } \\
\text {-Relationship } \\
\text {-Recognition } \\
\text { Determinants: } \\
\text {-Openness } \\
\text {-Conscientiousness } \\
\text {-Extraversion } \\
\text {-Agreeableness } \\
\text {-Neuroticism } \\
\text {-Gender } \\
\text {-Age } \\
\text {-Project genre } \\
\text {-Funding duration } \\
\text {-Funding amount } \\
\text {-Funding timing }\end{array}$ & $\begin{array}{l}\text { There are four types of } \\
\text { crowdfunders depending on } \\
\text { motivation to participate, } \\
\text { personality, demographic, } \\
\text { and project characteristics }\end{array}$ \\
\hline$[88]$ & $\begin{array}{l}\text { Quantitative (survey of } \\
204 \text { investors) }\end{array}$ & $\begin{array}{l}\text { DV: Funding intention } \\
\text { IV: Perceived risk, commitment }\end{array}$ & $\begin{array}{l}\text { Commitment and perceived } \\
\text { risk have a positive effect on } \\
\text { funding intention }\end{array}$ \\
\hline
\end{tabular}

Notes: $\mathrm{DV}=$ dependent variable; $\mathrm{IV}=$ =independent variable

[12] identified three main motivations of capital-seekers for using crowdfunding: collecting funds, attaining public attention, and obtaining feedback. [28] came to similar conclusions, identifying five categories of motivations to use crowdfunding: financing, forming relationships and networks, self-affirmation, replication of success stories, and increasing product awareness. The literature on crowdfunding has recently turned ITS attention to the study of motivations to participate in this activity. According to [21], [37], [79], individuals may be extrinsically or intrinsically motivated to participate in crowdfunding projects. When a project has intrinsic rewards, the motivation to participate will be intrinsic and vice versa. Crowdfunding may be extrinsically motivated when it is accomplished in order to achieve a significant outcome [79]. Previous studies have revealed the positive effect of extrinsic motivations as a determinant of crowdfunding participation. Most have concluded that the decision to participate is predicted by individuals' interest in receiving economic rewards [21], [37], [79]. Individuals can also be extrinsically motivated to achieve social recognition in exchange for their contribution to the project [63], [79].

Previous studies have highlighted the importance of intrinsic motivations [36]. However, very little is known about intrinsic motivations, and conflicting results have been observed in recent literature. Interest in helping others [36], [79], interest in the project [79], or the desire to become part of a community [36] have been identified as predictors of participation in crowdfunding projects. In contrast, [21] found that nonfinancial motives do not play a significant role in the decision to participate.

Individuals may not expect any extrinsic reward in exchange for their participation. Their participation may rather be driven by intrinsic motivations. Self-determination theory (SDT) suggests that the extent to which an individual is intrinsically motivated can be affected by their personal traits; that is, that certain personal characteristics could lead individuals to be intrinsically motivated to something [27]. In this sense, personal traits could lead individuals to be intrinsically motivated to participate in crowdfunding. Therefore, it is used as the theoretical framework for this study.

\subsection{Self-Determination Theory and Motivations to Participate in Crowdfunding}

SDT explores the motivations that people can have for their actions, addressing individual differences in general motivational orientations [23], [25]. It distinguishes between different types of motivations based on the various reasons or goals that give rise to an action [24]. The most basic distinction is between intrinsic motivation, which 
refers to doing something because it is inherently interesting or enjoyable, and extrinsic motivation, which refers to doing something because it leads to a separable outcome [78].

SDT assumes that the human organism is evolved to be inherently active and intrinsically motivated [23]. According to [36], intrinsic motivation will enhance activities that hold intrinsic interest for an individual-i.e., those that have the appeal of novelty, challenge, or aesthetic value for that individual. In a similar vein, [62] stated that people are intrinsically motivated when they do something they find interesting, personally important, or satisfying. This interest, importance, and satisfaction can represent the reward itself [78]. Therefore, SDT may be very useful to assess the role of intrinsic motivations in crowdfunding, since participation could be seen as a reward in itself.

In addition, SDT argues that the fulfillment of basic social needs, such as an individual's feelings of competence, autonomy, and relatedness, are the basis for maintaining intrinsic motivations to perform actions. Competence represents the perceived self-efficacy in performing a task [43], autonomy captures the self-determination of the individual's behavior [22], and relatedness addresses whether the behavior is valued by others to whom the individual feels connected [23]. All of these-competence, autonomy, and relatedness-may be fulfilled through participation in a crowdfunding project. However, the way consumers satisfy these needs describes their innate personal characteristics [68]; that is, individuals' motivation to participate in crowdfunding projects will vary depending on the individuals' personal traits. Many individuals may be intrinsically motivated to participate in crowdfunding. The question is, who among the general audience is most prone to participate?

\subsection{Altruism as a Determinant of Participation in Crowdfunding}

According to recent research on crowdfunding [15], [79], personal traits can determine the intention to participate in crowdfunding. Altruism has been selected in this study because it may be one of those personal traits that intrinsically motivate individuals to participate in crowdfunding projects. [61] confirmed that many contributions in crowdfunding have altruistic motivations. In addition, altruism has recently been examined as a motive to participate in crowdfunding projects [37], [79].

Altruism is defined as feeling on behalf of the welfare of others in cases where self-interest is not necessarily involved [50]. It covers a wide range of behaviors. Literature has shown that how people feel about helping others may affect their behavior [71]. This may also be applied to crowdfunding, such that participation in crowdfunding is perceived by individuals as a way of helping capital-seekers, as well as contributing to the final outcome of the project. Consequently, altruism may intrinsically motivate people to participate in crowdfunding projects. Previous studies have analyzed altruism as a motive to participate in crowdfunding [37], [79]; however, altruism can also be a personal trait [7]. This motivation may vary from one individual to another. Research on altruism has shown that some individuals are more altruistic than others [30]. Thus, this study also considers altruism as a personality trait [16], [30], and explores its influence on participation in crowdfunding.

SDT also supports the inclusion of altruism in the proposed model. As we stated above, the three social needs that are essential for optimal development-competence, autonomy, and relatedness-may be fulfilled through participation in crowdfunding. However, individual differences that support the satisfaction of these basic needs may facilitate intrinsically motivated behavior [23]. Altruism may be one such individual difference. In addition, SDT has revealed the relevance of many social issues, such as prosocial behaviors [86]. Since crowdfunding can be considered prosocial [18], it is very likely that more altruistic individuals could be more intrinsically motivated to participate in crowdfunding compared to less altruistic individuals.

Crowdfunding combines elements of online philanthropic behavior, online consumer behavior, and online peer-topeer lending [36]. In this line of reasoning, previous studies [17], [21], [36] have established a relationship between altruism and participation in altruistic projects. In projects where donations are anonymous, [17] clearly documented altruism as a reason for such support. In the context of theater fundraising, [14] found that crowdfunders invest because they consider their investment to be altruistic. Additionally, [21] proposed that intrinsic motives, such as helping others, play a major role in explaining why people decide to participate in CFPs. Furthermore, [36] identified the desire to support important causes and to help others as supporter motivations. Following these arguments, we propose that:

\section{H1: Altruism has a positive effect on intention to participate in crowdfunding.}

\subsection{Internal Locus of Control as a Determinant of Participation in Crowdfunding}

The ability to control the outcome of a given task is assumed to play an important role in individuals' actions, motivations, and achievements [85]. LOC refers to the beliefs that individuals hold about their role in influencing events in their lives [46]. According to [76], an individual can perceive the outcome of an event as being either within (internal LOC) or beyond (external LOC) their personal control. Individuals with an internal LOC consider that they have control over their behavior and can influence outcomes in their lives [76]. 
Individuals' participation in a crowdfunding project is the key factor for the success of the supported project. Individuals with an internal LOC may perceive that they have some kind of responsibility for the success of the project, and may therefore decide to contribute. The reason behind this expectation is that individuals with an internal LOC may see their decision to participate as a way of impacting the final outcome of the project. Individuals with an internal LOC believe they can control a broad array of factors in their lives [49], and may thus be more prone to take part in crowdfunding projects. In contrast, external-LOC individuals will perceive the outcome of a crowdfunding project as beyond their personal control, and may thus be less motivated to participate. Therefore, we focus on internal LOC as a personality trait that may determine individuals' intention to participate in crowdfunding projects.

Internal LOC is closely related to the basic needs of autonomy and competence explained in SDT [26]. The concept of intrinsic motivation used in SDT fits with this assertion in that people have a primary motivational propensity to feel like causal agents with respect to their own actions [24]. Such a propensity may be more intense among those with an internal LOC. Additionally, [27] proposed that intrinsically motivated behaviors are based on people's need to feel competent and self-determined. However, feelings of competence will not enhance intrinsic motivation unless they are accompanied by a sense of autonomy [22], [24]. Choice and the opportunity for self-direction appear to enhance intrinsic motivation, as they afford a greater sense of autonomy [86]. Therefore, we assume that individuals with a high internal LOC, who believe that the outcomes of their lives are contingent on their behaviors [76], will have a higher intrinsic motivation to participate in crowdfunding compared to their counterparts (individuals with low internal LOC) as a means of fulfilling their needs for competence and autonomy. An individual with high internal LOC may perceive that a project's success (seen as an outcome of their lives) depends on their participation (required behavior for that success).

Since individuals with an internal LOC believe they can control a broad array of factors in their lives [49], they may be more prone to participate in crowdfunding since they have control over the decision to participate or not. In a similar vein, [96] found a significant relationship between individuals' internal LOC and their intention to invest in financial projects. Moreover, [34] established activities such as control over the product or the project that is developed as motivators to participate in crowdsourcing. Given the similarities between crowdsourcing and crowdfunding [44], we assume that having control over the success of the project will also be important for participation in crowdfunding activities. Since consumers with a high internal LOC believe that they can control their behavior and environment, and also influence outcomes in their lives, we further assume that this personality trait will affect consumers' intention to participate in crowdfunding. Therefore, we propose:

\section{H2: Internal LOC has a positive effect on intention to participate in crowdfunding.}

\subsection{The Mediating Role of Trust in the Intention to Participate in Crowdfunding}

Efforts to use personality traits as a single predictor of consumer behavior have produced unconvincing results because the relations between personality traits and behaviors are often relatively modest in magnitude [19]. Taken alone, personality traits explain only a small portion of the variance in a specific behavior [39]. Therefore, without any other relevant information, it may be very difficult to provide a clear-cut assessment of participation in crowdfunding. Trust is introduced in this study in order to better explain the intention to participate in crowdfunding. There are several reasons for its inclusion. First, trust is a relevant factor in making decisions in an online context, where there is large amount of uncertainty [49]. Second, trust is related to the two personality traits we study here-i.e., altruism and internal LOC.

Trust can be defined as a social lubricant that mitigates individuals' perception of risks [49]. In crowdfunding projects individuals cannot fully evaluate products or services, which can accentuate some trust-related concerns. Given that crowdfunding is a novel, Web-based phenomenon with a great deal of uncertainty [47], trust in crowdfunding should play a significant role in our proposed model. CFPs are also becoming aware of the importance of trust for their businesses. For instance, two of the most popular platforms, Kickstarter and Indiegogo, include a Trust and Safety section on their sites. Moreover, [37] supported this argument by stating that supporters must rely on personal and trusting connections with supporters.

The role of trust has been largely explored in the literature on decision making in online contexts [49], [70]. Therefore, trust appears to be a major determinant of people's willingness to interact in online environments [49]. It also facilitates borrowing and lending between individuals in online marketplaces [41], which surround the crowdfunding concept. Finally, trust is related to personality traits. For instance, [65] linked agreeableness to interpersonal trust. Most extant research has shown that personality traits are a relevant factor that can affect people's trust [80]; therefore, the two personality traits included in this study, altruism and internal LOC, are incorporated as antecedents of trust in the model. The following discussion justifies the proposed relationships between altruism and internal LOC, and trust.

People are motivated to reach a range of goals [62]. Intrinsic motivations usually lead to reaching intrinsic goals. These goals are gratifying in their own right and tend to directly satisfy people's basic psychological needs [37]. Specifically, altruistic individuals can feel rewarded by the mere act of participating in crowdfunding projects. According to previous research, altruistic individuals will experience positive emotions when their contribution is effective [12]; thus, in crowdfunding terms, altruistic individuals will experience positive emotions when their 
participation helps the project. In such a situation, altruistic individuals will have similar goals to capital-seekers, as the concern of both is for the success of the project. One of the effects of sharing goals when individuals cooperate is a high level of confidence in the others' ideas [27]. This higher confidence in capital-seekers' ideas could lead to higher trust in crowdfunding.

Previous studies on altruism have also supported this relationship. In this vein, [33] found that altruism is associated with individuals' propensity to trust. Furthermore, [60] recognized altruistic behavior as a basis for trust. People who are altruistic are expected to be more trustworthy, and therefore will place more trust in cooperative projects [31]. Since crowdfunding is closely related to collaboration and cooperation, the extent to which a person is altruistic may determine their trust in crowdfunding. Based on the above reasoning, we propose the following hypothesis:

\section{H3: Altruism has a positive effect on individuals' trust in crowdfunding.}

SDT also helps to support the relationship between internal LOC and trust. As we stated above, participating in crowdfunding could serve to satisfy the need for relatedness. Participation offers feelings of connectedness to a community with similar interests and ideas, and gives them the opportunity to interact with a likeminded group of people [35], [48]. Supporters could feel that they are part of a select group [10]. However, this feeling will vary among individuals depending on their internal LOC. Individuals with a high internal LOC will value the social benefits that crowdfunding offers more compared to individuals with a low internal LOC. In fact, people with a high LOC will work more actively to establish and maintain positive relationships with others [67]. Therefore, individuals with a high internal LOC will be more prone to develop connections with other people who support the same project as them. Such connectedness will, in turn, lead to higher levels of trust [36].

Several studies have examined the relationship between internal LOC and trust. In research on the correlates of trust, [33] found that a trusted person is one who, among other things, has an internal LOC. Similarly, [20] observed that trust is based on several individual predispositions, including internal LOC. In a business context, [30] found that chief executives with an internal LOC tended to take greater risks in their decisions. Since trust mitigates the perception of risks [49], a relationship between internal LOC and trust may also be inferred from this study. Therefore, we propose the following hypothesis:

\section{H4: Internal LOC has a positive effect on individuals' trust in crowdfunding.}

In order to justify the proposed mediation, we draw from [82], whose study explored the mediating role of trust in the relationship between personality traits and giving behavior. Their results demonstrated that trust is a significant predictor of giving behavior or helping behavior. Likewise, [6] established the mediating role of trust between individuals' personal traits and purchase intentions in online markets.

Based on this evidence, we propose that trust will mediate the relationship between individuals' personal traits and intention to participate in crowdfunding. In line with this proposition, [28] emphasized the importance of trust in crowdfunding. However, little academic research has attempted to confirm empirically the factors that affect trust in crowdfunding. Thus, $\mathrm{H} 1$ and $\mathrm{H} 2$ propose that altruism and internal LOC may be antecedents of trust.

Previous research on trust can be very useful to infer the consequences of trust in crowdfunding. For instance, the role of trust in individuals' decision-making process has been broadly analyzed [42], [77], while according to [48], trust acts as an antecedent of investors' decision making. Crowdfunding is no exception; indeed, trust is important in crowdfunding as problems such as fraud, lack of professional project screening, and gambling with the crowd's money have been identified as issues therein [63].

Given that actual and potential supporters are worried about the appropriate use of their money, distrust in crowdfunding is a deterrent to participation [12]. Similarly, [17] provided empirical evidence of a positive effect of ITbased trust mechanisms on raising microcredits in lending CFPs. Likewise, [28] established that entrepreneurs who appear more trustworthy have better credit scores, attesting that impressions of trustworthiness matter and can predict supporters' behavior. Moreover, [21] suggested that trust in the project creator may affect intention to participate in CFPs. Therefore, trust in crowdfunding seems to be an important predictor of participation.

As established above, we suggest that altruism and internal LOC may impact individuals' intention to participate in crowdfunding. However, according to [19], the relations between personality traits and behavior can be better explained by investigating the role of mediating variables. Therefore, in the relationship between the two personality traits and participation, trust in crowdfunding should be added as a mediator. Taking into consideration our previous arguments about the influence of altruism and internal LOC on trust, and the fact that most efforts to use personality as a single predictor of consumer behavior have produced unconvincing results [19], [28], we propose that the impact of altruism and internal LOC on individuals' intention to participate in crowdfunding is mediated by trust. Therefore, we set the following hypothesis:

H5: Individuals' trust in crowdfunding partially mediates the relationship that (a) altruism and (b) internal LOC have on the intention to participate in crowdfunding. 
The proposed model is shown in Figure 1.

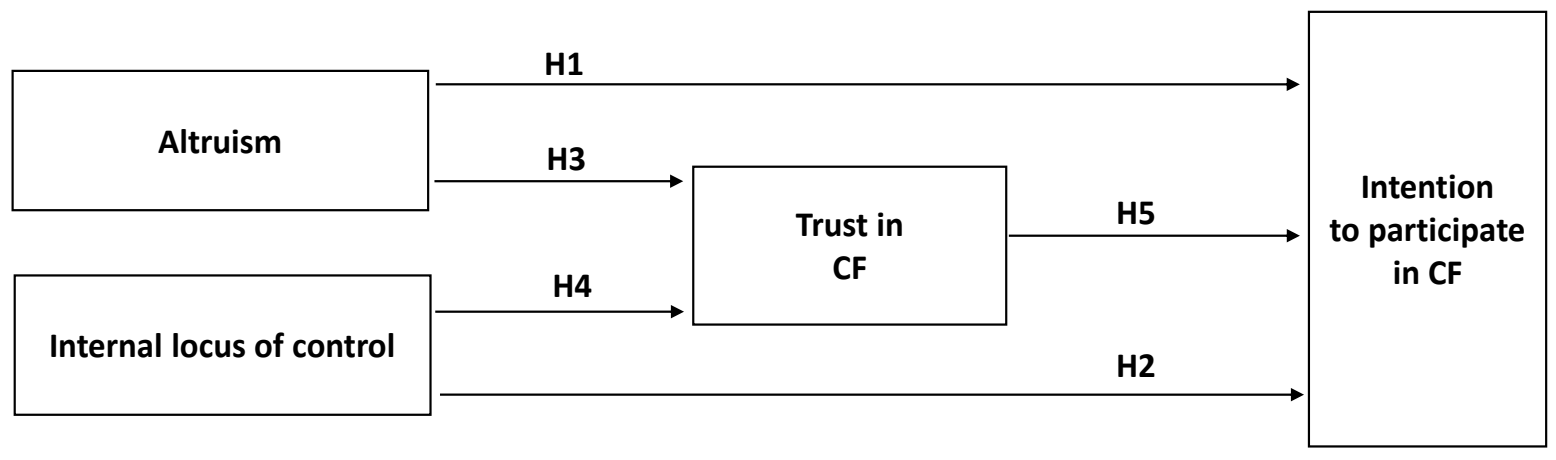

Figure 1: Theoretical model Note: $\mathrm{CF}=$ crowdfunding

\section{Method}

Data were gathered through an online panel. The survey was completed by 245 individuals, aged over 18, from Spain. The characteristics of the sample are as follows. Given that gender could be a determinant of participation in crowdfunding [5], [40] we decided to discount this effect by setting an equal sample distribution between male (50\%) and female (50\%) participants. Regarding age, our sample was between 18 and 64 years old. Most individuals (more than $43 \%$ ) in the sample were aged 18 to 30 .

The questionnaire began with a brief description of the crowdfunding concept, in order to facilitate individuals' responses to the various questions about crowdfunding. As many of the scales had to be adapted to the crowdfunding context, an initial pretest was needed to review and to make some improvements to the final version of the questionnaire (see scales in Table 2). After the description of the concept, intention to participate in crowdfunding was assessed, followed by trust in crowdfunding. To measure intention to participate and trust in crowdfunding, we drew from the first conceptualization of the Internet Consumer Trust Model developed by [49], which defines trust as a social driver that mitigates individuals' perception of risk. The two scales developed by [49], trust and intention to participate, were adapted to the crowdfunding context. Finally, to measure personality traits we also resorted to previous research. Altruism was assessed using the scale developed and validated by [84] to measure individuals' tendency to help others. Regarding internal LOC, we used the brief version of Levenson's LOC scale [56], developed by [81], which has shown good reliability and validity.

\subsection{Scale Validation}

We assessed the internal consistency and convergent validity of the measurement model by performing a confirmatory factor analysis (CFA) using $R$ with the lavaan package [75]. The results indicate that the measurement model fits the data well: $X^{2}=84.518$; degrees of freedom $(\mathrm{df})=59$; Tucker-Lewis Index $(\mathrm{TLI})=0.982$; Comparative Fit Index $(\mathrm{CFI})=0.986$; Incremental Fit Index (IFI) = 0.976; NonNormed Fit Index (NNFI) = 0.982; Root Mean Square Error of Approximation (RMSEA) $=0.042$. The TLI, CFI, and IFI are greater than 0.9, as recommended by [13]. Therefore, results of the CFA are satisfactory.

As shown in Table 2, the alpha coefficient values are equal to or greater than 0.70 , which indicates good reliability [69]. Furthermore, the composite reliability estimates exceed the standard of 0.6 suggested by [3]. Average Variance Extracted (AVE) values also provide satisfactory results according to [32], with the exception of internal LOC, which has an AVE slightly below 0.5 . Nonetheless, we decided to keep this measure because all the other parameters of reliability and consistency are acceptable. The standardized item loadings for all the constructs are significant $(p<0.05)$ and greater than 0.5 , thus serving as evidence of good convergent validity [4].

In order to assess discriminant validity, we used the criterion proposed by [32], given that all the measures used were reflective constructs (meaning that if we removed any item from the scale, the latent concept would remain the same as the correlations among latent variables). Discriminant validity was established by comparing the square root of the AVE (the diagonal in Table 3) with the correlations among latent variables. As shown in Table 3, for each reflective construct the square root of its AVE is greater than its correlation with any other construct, which means that it shares more common variance with its own items than with other concepts in the model. These results establish that all the measures included in this study have acceptable unidimensionality, reliability, and validity. 
Table 2: Reliability and convergent validity of the measurement model

\begin{tabular}{|c|c|c|c|c|}
\hline Latent variable/indicators & $\begin{array}{l}\text { Factor } \\
\text { loading }\end{array}$ & CA & AVE & CR \\
\hline \multicolumn{2}{|l|}{ Intention to participate in crowdfunding } & \multirow[t]{4}{*}{0.91} & \multirow[t]{4}{*}{0.79} & \multirow[t]{4}{*}{0.92} \\
\hline $\begin{array}{l}\text { Given the chance, I would intend to participate in crowdfunding } \\
\text { projects. }\end{array}$ & $0.879^{* * *}$ & & & \\
\hline $\begin{array}{l}\text { Given the chance, I predict that I would participate in a crowdfunding } \\
\text { project in the future. }\end{array}$ & $0.884^{\star * \star}$ & & & \\
\hline $\begin{array}{l}\text { It is very likely that I will participate in a crowdfunding project in the } \\
\text { near future. }\end{array}$ & $0.900^{* * *}$ & & & \\
\hline \multicolumn{2}{|l|}{ Trust in crowdfunding } & \multirow[t]{4}{*}{0.91} & \multirow[t]{4}{*}{0.75} & \multirow[t]{4}{*}{0.90} \\
\hline The crowdfunding system is trustworthy. & $0.860^{* * *}$ & & & \\
\hline $\begin{array}{l}\text { The crowdfunding system keeps promises and commitments to } \\
\text { consumers. }\end{array}$ & $0.894^{* * *}$ & & & \\
\hline I trust in crowdfunding because it keeps my best interests in mind. & $0.850^{* * *}$ & & & \\
\hline \multicolumn{2}{|l|}{ Altruism } & \multirow[t]{5}{*}{0.89} & \multirow[t]{5}{*}{0.67} & \multirow[t]{5}{*}{0.89} \\
\hline People should be willing to help others who are less fortunate. & $0.850^{* * *}$ & & & \\
\hline Helping people with their problems is very important to me. & $0.845^{\star * *}$ & & & \\
\hline People should be more charitable towards others in society. & $0.741^{* \star \star}$ & & & \\
\hline People in need should receive support from others. & $0.827^{\star \star \star}$ & & & \\
\hline \multicolumn{2}{|l|}{ Internal locus of control } & \multirow[t]{4}{*}{0.72} & \multirow[t]{4}{*}{0.47} & \multirow[t]{4}{*}{0.73} \\
\hline When I make plans, I am almost certain to make them work. & $0.600^{* * *}$ & & & \\
\hline $\begin{array}{l}\text { Getting people to do the right thing depends on ability; luck has nothing } \\
\text { to do with it. }\end{array}$ & $0.728^{\star * \star}$ & & & \\
\hline What happens to me is my own doing. & $0.724^{\star \star \star}$ & & & \\
\hline
\end{tabular}

Table 3: Discriminant validity of the measurement model

\begin{tabular}{|l|l|l|l|l|}
\hline & $\begin{array}{l}\text { Trust in } \\
\text { crowdfunding }\end{array}$ & $\begin{array}{l}\text { Intention to } \\
\text { participate in } \\
\text { crowdfunding }\end{array}$ & Altruism & $\begin{array}{l}\text { Internal } \\
\text { locus of } \\
\text { control }\end{array}$ \\
\hline Trust in crowdfunding & 0.87 & & & \\
\hline $\begin{array}{l}\text { Intention to participate in } \\
\text { crowdfundina }\end{array}$ & 0.67 & 0.89 & & \\
\hline Altruism & 0.34 & 0.37 & 0.82 & \\
\hline Internal locus of control & 0.29 & 0.27 & 0.32 & 0.67 \\
\hline
\end{tabular}

Note: Matrix shows square roots of AVE (diagonal) and correlation (below the diagonal).

\section{Results}

The research hypotheses were tested using structural equation modeling. Results of the hypothesized structural model performed using $R$ are summarized in Figure 2. The structural model fits the data well: $X^{2}=89.208 ; \mathrm{df}=60$; $\mathrm{TLI}=0.979 ; \mathrm{CFI}=0.984 ; \mathrm{IFI}=0.979 ; \mathrm{NNFI}=0.979 ; \mathrm{RMSEA}=0.045$. TLI, CFI, and IFI are all greater than 0.9, as recommended by [13].

Figure 2 and Table 4 show the standardized path coefficients $(\beta)$, the significance level (statistic), and the R-squared value of the dependent variables. As can be observed in Figure 2, we found a positive and significant relationship between altruism and intention to participate in crowdfunding $(\mathrm{H} 1, \beta=0.167, \mathrm{p}<0.05)$, leading to acceptance of $\mathrm{H} 1$. However, internal LOC did not impact the intention to participate $(H 2, \beta=0.099, p>0.10)$; thus, $H 2$ is not supported. In addition, the hypotheses testing the relationship between personal determinants and trust in crowdfunding are supported, which means that altruism $(H 3, \beta=0.261, p<0.01)$ and internal $\operatorname{LOC}(H 4, \beta=0.386, p<0.01)$ are positively related to trust in crowdfunding. Therefore, $\mathrm{H} 3$ and $\mathrm{H} 4$ are both supported. 


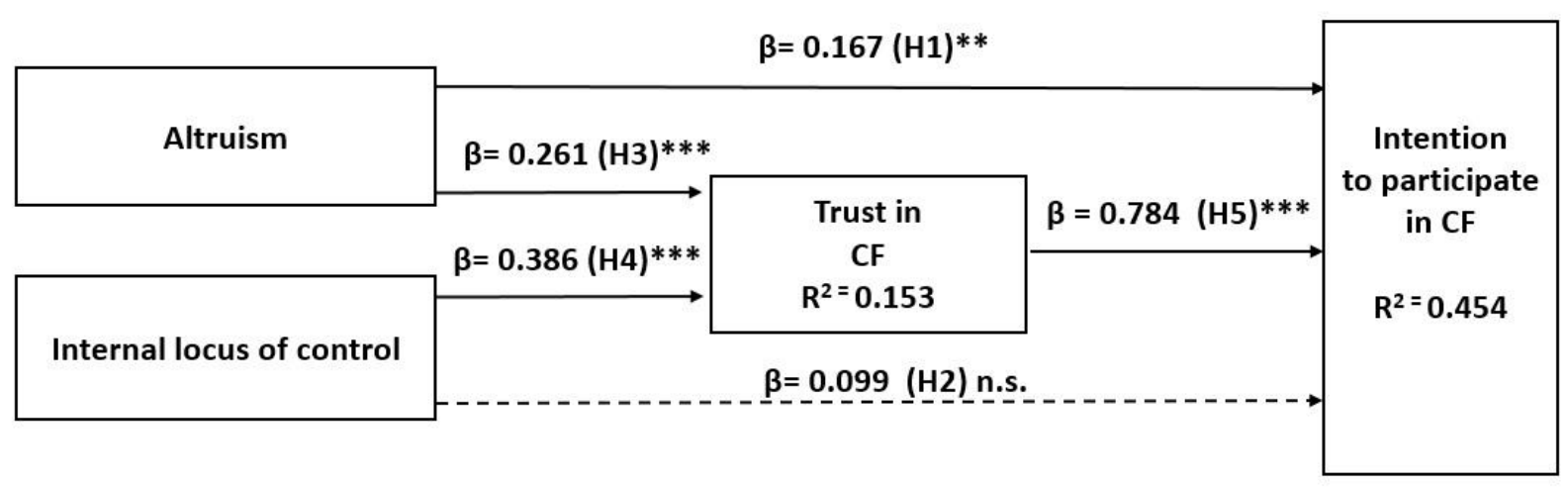

Figure 2: Hypothesized structural model

Note: $\mathrm{CF}=$ crowdfunding; ${ }^{* *} \mathrm{p}<0.05,{ }^{* * *} \mathrm{p}<0.01$

Table 4: Results for hypothesized structural model

\begin{tabular}{|l|l|}
\hline \multicolumn{1}{|c|}{ Structural path } & $\begin{array}{l}\text { Theoretical model } \\
\text { standardized coefficients } \\
(\text { Z-value })\end{array}$ \\
\hline H1: Altruism-Intention to participate in CF & $0.167(2.177)^{\star \star}$ \\
\hline H2: Internal LOC-Intention to participate in CF & $0.099(0.575)$ n.s. \\
\hline H3: Altruism-Trust in CF & $0.261(3.783)^{\star \star *}$ \\
\hline H4: Internal LOC-Trust in CF & $0.386(2.434)^{\star \star *}$ \\
\hline H5: Trust in CF-Intention to participate in CF & $0.784(8.812)^{\star * *}$ \\
\hline Goodness-of-fit indexes & \multicolumn{2}{|l}{} \\
\hline df & 60 \\
\hline$X^{2}$ & 89.208 \\
\hline NNFI & 0.979 \\
\hline CFI & 0.984 \\
\hline IFI & 0.979 \\
\hline TLI & 0.979 \\
\hline RMSEA & 0.045 \\
\hline
\end{tabular}

Notes: $\mathrm{CF}$ = crowdfunding; $\mathrm{CFI}=$ comparative fit index; df = degrees of freedom; IFI = incremental fit index; LOC = locus of control; NNFI = non-normed fit index; RMSEA = root mean square error of approximation; TLI = Tucker-Lewis index. ${ }^{* * *} p<.01 ;{ }^{* *} p<.05$.

Additionally, we explored the mediating effect of trust in crowdfunding in the model. We found that trust has a positive effect on intention to participate in crowdfunding $(\beta=0.784, p<0.01)$. Indirect effects were calculated using the Hayes Process Macros for SPSS, which applies significance levels based on bias-corrected bootstrap confidence intervals, as proposed by [73]. The bootstrapping test used provides a 95\% bias correction of the bootstrapped confidence interval. If zero is not included between the lower and upper limits, and the estimated effect remains between these two values, we can conclude that the indirect effects are significant [73]. In contrast, if zero is placed between these lower and upper limits, the mediation will be nonsignificant [73]. As shown in Table 5, our results support the mediation effect of trust in the relationship between altruism and intention to participate in crowdfunding ( $\beta=0.1749 ;[0.0516-0.2391])$. As altruism has a positive effect on intention to participate, trust in crowdfunding partially mediates the relationship between altruism and intention to participate, supporting H5a. Likewise, internal LOC has an indirect effect on intention to participate through trust in crowdfunding $(\beta=0.1487 ;[0.1442-0.2577])$; however, as internal LOC has no direct effect on intention to participate, trust in crowdfunding totally mediates the relationship between internal LOC and intention to participate. Thus, H5b is partially accepted.

Table 5: Indirect effects

\begin{tabular}{|l|l|l|}
\hline Indirect effect & Standardized coefficient & $\begin{array}{l}\text { Bias-corrected } \\
\text { bootstrapped } \\
\text { confidence Interval }\end{array}$ \\
\hline Altruism - Intention to participate in CF & 0.1749 & {$[0.0516-0.2391]$} \\
\hline Internal LOC - Intention to participate in CF & 0.1487 & {$[0.1442-0.2577]$} \\
\hline
\end{tabular}




\subsection{Rival Models}

As a final approach to model assessment, we compared the theoretical model proposed with another competing model to check for better fit. Following a nested approach, we compared the models by conducting a $\mathrm{X}^{2}$ difference test, among other statistical approaches.

The comparison model $\left(\mathrm{M}_{1}\right)$ excludes trust in crowdfunding. As shown in Table 6 , the chi-squared difference test is not significant; however, the $R^{2}$ is considerably better in the theoretical model $\left(M_{0}\right)$ than in the competing model ( $\left.M_{1}\right)$.

Therefore, the theoretical model is retained.

Table 6: Comparison among rival structural models

\begin{tabular}{|l|l|l|}
\hline $\begin{array}{l}\text { Structural } \\
\text { Path }\end{array}$ & $\begin{array}{l}\text { Theoretical Model } \\
\text { Mo } \\
\text { Standardized } \\
\text { Coefficients }\end{array}$ & $\begin{array}{l}\text { Competing Model } \\
\mathbf{M}_{1} \\
\text { Standardized } \\
\text { coefficients }\end{array}$ \\
\hline H1: Altruism-Intention to participate in CF & $0.167(2.177)^{\star *}$ & $0.402(1.976)^{* * *}$ \\
\hline H2: Internal LOC-Intention to participate in CF & $0.099(0.575)$ n.s. & $0.369(4.152)^{* * *}$ \\
\hline H3: Altruism-Trust in CF & $0.261(3.783)^{\star * *}$ & \\
\hline H4: Internal LOC-Trust in CF & $0.386(2.434)^{\star * *}$ & \\
\hline H5: Trust in CF-Intention to participate in CF & $0.784(8.812)^{\star * *}$ & \\
\hline Goodness-of-fit indexes & \multicolumn{2}{|l|}{} \\
\hline Degrees of freedom & 60 & 32 \\
\hline$X^{2}$ & 89.208 & 53 \\
\hline NNFI & 0.979 & 0.953 \\
\hline CFI & 0.984 & 0.983 \\
\hline IFI & 0.979 & 0.984 \\
\hline TLI & 0.979 & 0.977 \\
\hline RMSEA & 0.045 & 0.052 \\
\hline$R^{2}$ of intention to participate in crowdfunding & 0.454 & 0.148 \\
\hline$X^{2}$ difference test & & $\begin{array}{l}\mathrm{X}^{2} \mathrm{M}_{0} \mathrm{X}^{2} \mathrm{M}_{1} \\
(\mathrm{p}>0.1)\end{array}$ \\
\hline
\end{tabular}

Notes: $\mathrm{CF}=$ crowdfunding; $\mathrm{CFI}=$ comparative fit index; $\mathrm{df}=$ degrees of freedom; $\mathrm{IFI}=$ incremental fit index; $\mathrm{LOC}=$ locus of control; NNFI = non-normed fit index; RMSEA = root mean square error of approximation; TLI = TuckerLewis index. ${ }^{* * *} p<.01 ;{ }^{* *} p<.05$.

\section{Discussion}

This study analyzes the general audience as potential supporters of crowdfunding projects. Therefore, it provides an initial explanation of which personal traits of the general public affect their intention to participate in crowdfunding. It proposes a theoretical model in which trust in crowdfunding acts as a mediator between individuals' personal traits and intention to participate in crowdfunding. The extrinsic/intrinsic categorization of motivations proposed by SDT [26] was used to establish the hypotheses of the study. Results indicate that both altruism and internal LOC intrinsically motivate individuals' intention to participate in crowdfunding. However, the effect of these personal traits on participation is mediated by trust in crowdfunding.

This study contributes to the literature in several ways. First, data were collected from a general audience. Several extant studies have examined the determinants of participation for people who have already participated in crowdfunding [21], [79]; however, to the best of our knowledge, a sample from the general audience has not been previously analyzed in the crowdfunding literature. According to [57], any individual can be a potential supporter, so it is important to identify the drivers of participation in crowdfunding for a more general public.

Second, we contribute to the crowdfunding literature by highlighting personal traits that could intrinsically motivate consumers to participate in crowdfunding. Previous studies of motivations to participate in crowdfunding projects have highlighted the importance of extrinsic motivations such as economic rewards and social recognition [2], [37], [21]. However, the relevance of intrinsic motivations has been called into question; for instance, [21] found that intrinsic motives do not play a significant role in the decision to participate. Even less is known about personal traits 
that may intrinsically motivate individuals. Only one recent study [79], has identified specific supporter behaviors in the context of crowdfunding that could reflect differences in motivations. However, as [28] recognized, the relationship between motivations and behaviors was not elucidated in their research. In this sense, our study shows that altruism and internal LOC have to be considered as drivers of participation in crowdfunding.

The results obtained regarding altruism support those of previous research [35], [37], [61], which has postulated that people can be motivated to participate in these projects to help others. However, unlike previous research, we do not consider altruism as a motivation in itself; rather, we analyze it as a personal trait-that is, as an enduring tendency of some individuals. Regarding internal LOC, our findings reveal that individuals with a high internal LOC are not intrinsically motivated to participate in crowdfunding. Our findings confirm that the relationship between the two traits of individuals-altruism and internal LOC-and individuals' intention to participate in crowdfunding is mediated by trust in crowdfunding. This result ratifies research that has accentuated the role of trust in online markets [7], [49], and, more specifically, the role of trust in crowdfunding [28], [36], [47]. The observed mediation effect indicates that trust is a key determinant of participation in crowdfunding. It is very difficult for individuals who distrust the crowdfunding system to participate in it. This result is in line with previous findings that personal traits explain only a small portion of the variance in a specific behavior [28], [39], and confirm that mediating variables are needed to better explain the relationship between personality traits and behavior [19]. From the results obtained, we can deduce that individuals who may be more prone to participate in these projects still need to trust in crowdfunding before participating. Therefore, trust should be paid greater attention in future crowdfunding research. Since trust in crowdfunding seems to be critical to stimulate participation, crowdfunding research has to focus more on how trust may be enhanced, as a way to stimulate participation among the general public.

\subsection{Managerial Implications}

Crowdfunding is rapidly expanding in many countries, although it is still considered a niche phenomenon. Companies and entrepreneurs currently using, or expecting to use, crowdfunding should take into account that any consumer may be a potential supporter. Thus, incorporating the general audience into this phenomenon may help to accelerate its growth. In this vein, our results reveal that the general audience represents an excellent opportunity for crowdfunding expansion. If companies want to expand the scope of potential crowdfunding supporters, their marketing campaigns should also be addressed to the general public.

Based on these results, campaigns designed to attract the general public should highlight the importance of trust for stimulating participation. Besides communication, entrepreneurs and companies should manage their personal or corporate identities effectively by offering high-quality and transparent information about the project, the company, and the project creators, and they should also work on and manage their social reputation and build a trustworthy appearance. Working on trust seems to be essential for extending crowdfunding to the general public.

Our findings also indicate that not all individuals may be equally predisposed to participate. Therefore, marketing campaigns intended to stimulate individuals' participation should focus on people with high levels of altruism and internal LOC. Individuals who follow brands such as Peace Corporation or who describe themselves as selfdetermined in their social media profiles may be prime targets for these campaigns. Likewise, social networking tools may be very useful to develop this market segmentation. For instance, by using a tool called ManageFlitter we found that 477 people on Twitter have included the expression self-determined in their bio [58]. These individuals may represent the perfect target for crowdfunding campaigns.

Crowdfunding may also be used to obtain feedback from consumers, for market testing and validation of new products or services, or as a promotional device for start-ups, entrepreneurs, and small companies at an early stage. As per [9], crowdfunding could be used to enhance knowledge of consumers' preferences.

\subsection{Limitations and Future Research}

In assessing the contributions of this study and interpreting the results discussed above, it is also important to take into account its limitations. One of the main drawbacks of the study is that we did not ask individuals about any specific project or type of crowdfunding. Instead, questions were based on general statements about crowdfunding in order to obtain initial knowledge of the reaction of the general public towards the phenomenon. However, results may vary depending on the type of project in question. Another limitation is that we did not ask for users' previous experience of crowdfunding, since the objective was to analyze the personal and social determinants that might explain intention to participate in the activity for actual and potential participants. However, results could vary depending on previous experience with these types of projects. Thus, future research could test any moderating effect that previous experience in crowdfunding projects has on the proposed model.

Furthermore, the measure intention to participate in crowdfunding only reflects a behavioral intention toward crowdfunding, and could have limited scope for generalizability. Given that all the measures used in the paper are self-reported, they may suffer from common method bias, though all of them show robustness and reliability. Therefore, we encourage future researchers in crowdfunding to analyze empirical measures from crowdfunding platforms (CFPs). Data related to success in terms of collecting the amount of money needed for the project, the 
number of days in which the money was collected, the number of crowdfunders that participated in the campaign, the social characteristics of the campaign (number of comments, use of social network sites for the capital-seeker, etc.), or the incentives of the capital-seeker could be useful to analyze this phenomenon. Moreover, to improve the validity of these results, researchers could combine self-reported measures from real crowdfunders with empirical data from CFPs to establish the relationship between consumers' self-reported measures and empirical data. Likewise, we recommend analyzing individuals with no previous experience in crowdfunding to compare these results with those obtained from people who have already participated. Additionally, researchers should apply different methodologies, such as experimental data, to compare the data obtained with empirical data from CFPs.

Future research should also combine both intrinsic and extrinsic motivations to identify the main differences between both types of motivations. Furthermore, we have not considered variables such as individuals' level of innovativeness or individuals' intentions to start their own business, which may relate to crowdfunding [21]. The influence of these variables on consumers' intention to participate in crowdfunding should be explored in future research. Finally, we have some concerns about the research sample, given that we solely used Spanish individuals as respondents, so future research could seek to use individuals from other countries in order to expand the results.

\section{Acknowledgments}

This research was supported by the Fundación Ramón Areces under the XVI National Contest for the Adjudication of Aids to Research in Social Sciences.

\section{References}

[1] A. K. Agrawal, C. Catalini and A. Goldfarb, The geography of crowdfunding, National Buoreau of Economic Research, Cambridge, MA, USA, working paper No. 16820, 2011.

[2] T. H. Allison, B. C. Davis, J. C. Short, and J. W. Webb, Crowdfunding in a prosocial microlending environment: examining the role of intrinsic versus extrinsic cues, Entrepreneurship Theory and Practice, vol. 39, no. 1, pp. 53-73, 2015.

[3] R. P. Bagozzi and Y. Yi, On the evaluation of structural equation models, Journal of the Academy of Marketing Science, vol. 16, no. 1, pp. 74-94, 1988.

[4] R. P. Bagozzi, Y. Yi and L. Phillips, Assessing construct validity in organizational research, Administrative Science Quarterly, vol. 36, no. 3, pp. 421-458, 1991.

[5] N. Barasinska and D. Schäfer, Is crowdfunding different? Evidence on the relation between gender and funding success from a German peer-to-peer lending platform, German Economic Review, vol. 15, no. 4, pp. 436-452, 2014.

[6] V. Bart, V. Shankar, F. Sultan, and G. Urban, Are the drivers and role of online trust the same for all web sites and consumers? A large-scale exploratory empirical study, Journal of Marketing, vol. 69, no. 4, pp. 133-152, 2005.

[7] E. P. Becerra and P. Korgaonkar, Effects of trust beliefs on consumers' online intentions, European Journal of Marketing, vol. 45, no. 6, pp. 936-962, 2011.

[8] R. Bekkers and P. Wiepking, A literature review of empirical studies of philanthropy, Nonprofit and Voluntary Sector Quarterly, vol. 40, no. 5, pp. 924-973, 2011.

[9] P. Belleflamme and T. Lambert, Crowdfunding: Some empirical findings and microeconomic underpinnings, Forum Financier: Revue Bancaire et Financière, vol. 2014, no. 4, pp. 288-296, 2014.

[10] P. Belleflamme, T. Lambert and A. Schwienbacher, Crowdfunding: Tapping the right crowd, Journal of Business Venturing, vol. 29, no. 5, pp. 585-609, 2014.

[11] P. Belleflamme, T. Lambert and A. Schwienbacher, Individual crowdfunding practices, Venture Capital, vol. 15, no. 4, pp. 313-333, 2013

[12] P. Belleflamme, T. Lambert and A. Schwienbacher. (2010, June) Crowdfunding: An industrial organization perspective. Citeseerx. [Online]. Available: http://citeseerx.ist.psu.edu/viewdoc/download?doi=10.1.1.416.4643 \&rep=rep1\&type $=$ pdf

[13] P. M. Bentler and D. G. Bonett, Significance tests and goodness of fit in the analysis of covariance structures, Psychological Bulletin, vol. 88, no. 3, pp. 588-606, 1980.

[14] B. Bœuf, J. Darveau and R. Legoux, Financing creativity: Crowdfunding as a new approach for theatre projects, International Journal of Arts Management, vol. 16, no. 3, pp. 33-48, 2014.

[15] V. Brancaleone and J. Gountas, Personality characteristics of market mavens, in ACR North American Advances, volume 34 (G. Fitzsimons and V. Morwitz, Eds.). Duluth, MN : Association for Consumer Research, 2007, pp. 522- 527.

[16] J. Breitsohl, M. Khammash and G. Griffiths, Managing negative epinion-leaders: A personality-based model of silver surfers' E-WOM, in Proceedings European Marketing Academy 41st Annual Conference, Lisbon, Portugal, 2012, pp. 51-57.

[17] G. Burtch, An empirical examination of the antecedents and consequences of contribution patterns in crowdfunded markets, Information Systems Research, vol. 24, no. 3, pp. 499-519, 2013.

[18] G. Calic and E. Mosakowski, Kicking off social entrepreneurship: How a sustainability orientation influences crowdfunding success, Journal of Management Studies, vol. 53, no. 5, pp. 738-767, 2016. 
[19] G. Carlo, M. Okun and G. Knight, The interplay of traits and motives on volunteering: Agreeableness, extraversion and prosocial value motivation, Personality and Individual Differences, vol. 38, no. 6, pp. 12931305, 2005.

[20] D. G. Carnevale and B. Wechsler, Trust in the public sector: Individual and organizational determinants, Administration \& Society, vol. 23, no. 4, pp. 471-494, 1992.

[21] M. Cholakova and B. Clarysse, Does the possibility to make equity investments in crowdfunding projects crowd out reward-based investments?, Entrepreneurship Theory and Practice, vol. 39, no. 1, pp. 145-172, 2015.

[22] R. De Charms, Personal Causation. New York: Routledge, 1968.

[23] E. L. Deci and R. Ryan, Handbook of Theories of Social Psychology. United States of America: Sage Publications, 2012.

[24] E. L. Deci and R. M. R. Ryan, The what and why of goal pursuits: Human needs and the self-determination of behavior, Psychological Inquiry, vol. 11, no. 4, pp. 227-268, 2000.

[25] E. L. Deci and R. Ryan, Intrinsic Motivation and Self-Determination in Human Behavior. New York: Plenum,1985.

[26] E. L. Deci, Applications of research on the effects of rewards, in The Hidden Costs of Reward: New Perspectives on the Psychology of Human Motivation (M. R. Lepper and D. Greene, Eds.). New York: Lawrence Erlbaum Associates, Inc., 1978, pp. 193-203.

[27] M. Deutsch, A theory of cooperation-competition and beyond, in Handbook of Theories of Social Psychology, (P. A. M. Van Lange, A. W. Kruglanski and E. T. Higgins, Eds.). London: SAGE Publications, 2012, pp. 73-294.

[28] J. Duarte, S. Siegel and L. Young, Trust and credit: The role of appearance in peer-to-peer lending, The Review of Financial Studies, vol. 25, no. 8, pp. 2455-2483, 2012.

[29] Y. Dufour and P. Steane, Competitive paradigms on strategic change: Mapping the field and further research development, Strategic Change, vol. 15, no. 3, p. 129, 2006.

[30] N. Eisenberg, P. Miller and M. Schaller, The role of sympathy and altruistic personality traits in helping: $A$ reexamination, Journal of Personality, vol. 57, no. 1, pp. 41-67, 1989.

[31] S. Fehrler and W. Przepiorka, Charitable giving as a signal of trustworthiness: Disentangling the signaling benefits of altruistic acts, Evolution and Human Behavior, vol. 34, no. 2, pp. 139-145, 2013.

[32] C. Fornell and D. F. Larcker, Evaluating structural equation models with unobservable variables and measurement error, Journal of Marketing Research, vol. 18, no. 1, pp. 39-50, 1981

[33] T. Frost, D. V. Stimpson and M. R. Maughan, Some correlates of trust, The Journal of Psychology, vol. 99, no. 1, pp. 103-108, 1978

[34] R. Gatautis and E. Vitkauskaite, Crowdsourcing application in marketing activities, Procedia-Social and Behavioral Sciences, vol. 110, pp. 1243-1250, 2014.

[35] E. M. Gerber and J. Hui, Crowdfunding: Motivations and deterrents for participation, ACM Transactions on Computer-Human Interaction (TOCHI), vol. 20, no. 6, pp. 1-32, 2013.

[36] E. M. Gerber, M. Muller, R. Wash, L. C. Irani, A. Williams and E. F. Churchill, Crowdfunding: an emerging field of research, in Proccedings CHI'14 Extended Abstracts on Human Factors in Computing Systems, Toronto, 2014, pp. 1093-1098.

[37] E. M. Gerber, J. S. Hui and P.-Y. Kuo, Crowdfunding: Why people are motivated to post and fund projects on crowdfunding platforms, in Proceedings of the International Workshop on Design, Influence, and Social Technologies: Techniques, Impacts and Ethics, New York, NY: ACM, 2012, pp. 45-50.

[38] R. A. Ghosh, R. Glott, B. Krieger, and G. Robles, Free/libre and open source Software: Survey and study, FLOSS, International Institute of Infonomics University of Maastricht, The Netherlands, Berlín, Germany, Deliverable D18: FINAL REPORT, 2002.

[39] R. E. Goldsmith, J. Freiden and J. Eastman, The generality/specificity issue in consumer innovativeness research, Technovation, vol. 15, no. 10, pp. 601-612, 1995

[40] A D. Gorbatai and L. Nelson, Gender and the language of crowdfunding, Academy of Management Proceedings, vol. 2015, no. 1, pp. 15785, 2015

[41] M. E. Greiner and H. Wang, Building consumer-to-consumer trust in e-finance marketplaces: An empirical analysis, International Journal of Electronic Commerce, vol. 15, no. 2, pp. 105-136, 2010

[42] J. R. B. Halbesleben and A. R. Wheeler, To invest or not? The role of coworker support and trust in daily reciprocal gain spirals of helping behavior, Journal of Management, vol. 41, no. 6, pp. 1628-1650, 2012.

[43] S. Harter, Effectance motivation reconsidered. Toward a developmental model, Human Development, vol. 21, no. 1, pp. 34-64, 1978.

[44] J. Hemer, A snapshot on crowdfunding, Fraunhofer ISI, Karlsruhe, working papers firms and region No. R2/2011, 2011

[45] J. Hobbs, G. Grigore and M. Molesworth, Success in the management of crowdfunding projects in the creative industries, Internet Research, vol. 26, no. 1, pp. 146-166, 2016

[46] D. L. Hoffman and T. Novak, Locus of control, web use, and consumer attitudes toward internet regulation, Journal of Public Policy \& Marketing, vol. 22, no. 1, pp. 41-57, 2003.

[47] L. Hornuf and A. Schwienbacher. (2015, August) The emergence of crowdinvesting in Europe. LudwigMaximilians-Universität München. [Online]. Available: https://epub.ub.uni-muenchen.de/21388/1/Hornuf\%20 Schwienbacher\%20-20The\%20Emergence\%20of\%20Crowdinvesting\%20in\%20Europe.pdf

[48] J. S. Hui, E. Gerber and M. Greenberg, Easy money? The demands of crowdfunding work, Northwestern University, Segal Design Institute, Evanston, Technical Report no. 4, 2012.

[49] S. L. Jarvenpaa and N. Tractinsky, Consumer trust in an internet store: a cross-cultural validation, Journal of Computer-Mediated Communication, vol. 5, no. 2, 1999. 
[50] C. Jencks, Varieties of altruism, in Beyond Self-Interest (J. J. Mansbridge, Ed.). Chicago: The University of Chicago Press, 1990, pp. 53-67.

[51] Kickstarter. (2016, May) Stats. Kickstarter. [Online]. Available: www.kickstarter.com

[52] F. Kleemann, G. G. Voß and K. Rieder, Un(der)paid innovators: The commercial utilization of consumer work through crowdsourcing, Science, Technology \& Innovation Studies, vol. 4, no. 1, pp. 5-26, 2008.

[53] V. Kuppuswamy and B. Bayus, Crowdfunding creative ideas: The dynamics of project backers, in The Economics of Crowdfunding (D. Cumming and L. Hornuf, Eds.). Cham: Palgrave Macmillan, 2013, pp. 151-182.

[54] T. Lambert and A. Schwienbacher, An empirical analysis of crowdfunding, Social Science Research Network, Belgium, Working Paper no. 1578175, 2010

[55] O. M. Lehner, A literature reviewand research agenda for crowdfunding of social ventures, presented a The Research Colloquium on Social Entrepreneurship, University of Oxford, Skoll Center of SAID Business School, Oxford, July 22-25, 2012

[56] $\mathrm{H}$. Levenson, Activism and powerful others: Distinctions within the concept of internal-external control, Journal of Personality Assessment, vol. 38, no. 4, pp. 377-383, 1974.

[57] S. A. Macht and J. Weatherston, The benefits of online crowdfunding for fund-seeking business ventures, Strategic Change, vol. 23, no. 1-2, pp. 1-14, 2014.

[58] ManageFlitter. (2016, May) Manageflitter. Manageflitter. [Online]. Available: https://manageflitter.com

[59] Massolution. (2015, May) Crowdfunding industry report. Crowdfunding. [Online]. Available: https://www.crowdfunding.com/

[60] D. J. McAllister, Affect-and cognition-based trust as foundations for interpersonal cooperation in organizations, Academy of Management Journal, vol. 38, no. 1, pp. 24-59, 1995.

[61] J. Meer, Effects of the price of charitable giving: Evidence from an online crowdfunding platform, Journal of Economic Behavior \& Organization, vol. 103, pp. 113-124, 2014

[62] A. C. Moller, R. Ryan and E. Deci, Self-determination theory and public policy: Improving the quality of consumer decisions without using coercion, Journal of Public Policy \& Marketing, vol. 25, no. 1, pp. 104-116, 2006.

[63] E. Mollick, The dynamics of crowdfunding: An exploratory study, Journal of Business Venturing, vol. 29, no. 1, pp. 1-16, 2014.

[64] E. R. Mollick and V. Kuppuswamy. (2014, January) After the campaign: Outcomes of Crowdfunding. SSRN. [Online]. Available: https://poseidon01.ssrn.com/delivery.php?ID=9291040661160111271100990280910261 0900101506504104806806811300402709110700502010511103611712212203803603511709506601802408 0071107006090051027067113066014091068086120008046031112098078001118124020095123028015111 $030120079084118093090023014116023103068118 \& \mathrm{EXT}=\mathrm{pdf}$

[65] T. Mooradian, B. Renzl and K. Matzler, Who trusts? Personality, trust and knowledge sharing, Management Learning, vol. 37, no. 4, pp. 523-540, 2006

[66] A. Moritz and J. H. Block, Crowdfunding: A literature review and research directions, in Crowdfunding in Europe (D. Brüntje and O. Gajda, Eds.). Cham: Springer, 2016, pp. 25-53.

[67] T. W. H. Ng, K. L. Sorensen and L. T. Eby, Locus of control at work: a meta-analysis, Journal of Organizational Behavior: The International Journal of Industrial, Occupational and Organizational Psychology and Behavior, vol. 27, no. 8, pp. 1057-1087, 2006.

[68] N. Ntoumanis, A prospective study of participation in optional school physical education using a selfdetermination theory framework. Journal of Educational Psychology, vol. 97 no. 3, p. 444-480, 2005.

[69] J. C. Nunnally, Psychometric Theory. New York. NY: McGraw-Hill, 1978.

[70] P. A. Pavlou and D. Gefen, Building effective online marketplaces with institution-based trust, Information Systems Research, vol. 15, no. 1, pp. 37-59, 2004

[71] J. A. Piliavin and H. H. Charng, Altruism: A Review of Recent Theory and Research, Annual review of sociology, vol. 16, pp. 27-65, 1990.

[72] M. K. Poetz and M. Schreier, The value of crowdsourcing: Can users really compete with professionals in generating new product ideas?, Journal of Product Innovation Management, vol. 29, no. 2, pp. 245-256, 2012.

[73] K. J. Preacher and A. F. Hayes, SPSS and SAS procedures for estimating indirect effects in simple mediation models, Behavior Research Methods, Instruments, \& Computers, vol. 36, no. 4, pp. 717-731, Nov. 2004

[74] G. Robles, H. Scheider, I. Tretkowski, and N. Weber, Who Is Doing It?, A research on Libre Software developers, 2001

[75] Y. Rosseel, Lavaan: An R package for structural equation modeling, Journal of Statistical Software, vol. 48, no. 2, pp. 1-36, 2012.

[76] J. B. Rotter, Generalized expectancies for internal versus external control of reinforcement, Psychological monographs: General and Applied, vol. 80, no. 1, pp. 1-28, 1966.

[77] L. V. Ryan and A. K. Buchholtz, Trust, Risk, and Shareholder Decision Making: An Investor Perspective on Corporate Governance, Business Ethics Quarterly, vol. 11, no. 1, p. 177, 2001.

[78] R. M. Ryan and E. Deci, Intrinsic and extrinsic motivations: Classic definitions and new directions, Contemporary Educational Psychology, vol. 25, no. 1, pp. 54-67, 2000.

[79] S. Ryu and Y.-G. G. Kim, A typology of crowdfunding sponsors: Birds of a feather flock together?, Electronic Commerce Research and Applications, vol. 16, pp. 43-54, 2016.

[80] R. M. Sabatelli, R. Buck and A. Dreyer, Locus of control, interpersonal trust, and nonverbal communication accuracy, Journal of Personality and Social Psychology, vol. 44, no. 2, pp. 399-409, 1983.

[81] S. G. Sapp and W. Harrod, Reliability and validity of a brief version of Levenson's locus of control scale, Psychological Reports, vol. 72, no. 2, pp. 539-550., 1993. 
[82] A. Sargeant, J. Ford, and D. West, Perceptual determinants of nonprofit giving behavior, Journal of Business Research, vol. 59, no. 2, pp. 155-165, 2006.

[83] Universo crowdfunding, El Crowdfunding recaudó en España 113 millones de euros en 2016 | Universo Crowdfunding, 2016. [Online]. Available: https://www.universocrowdfunding.com/el-crowdfunding-recaudo-enespana-113-millones-de-euros-en-2016/. [Accessed: 17-Oct-2017].

[84] D. J. Webb, C. L. Green and T. G. Brashear, Development and Validation of Scales to Measure Attitudes Influencing Monetary Donations to Charitable Organizations, Journal of the Academy of Marketing Science, vol. 28, no. 2, pp. 299-309, 2000.

[85] B. Weiner, An attributional theory of achievement motivation and emotion, Psychological Review, vol. 92, no. 4, pp. 548-573, 1986.

[86] N. Weinstein and R. Ryan, When helping helps: autonomous motivation for prosocial behavior and its influence on well-being for the helper and recipient, Journal of Personality and Social Psychology, vol. 98, no. 2, pp. 222244, 2010.

[87] Y. Yi and T. Gong, Customer value co-creation behavior: Scale development and validation, Journal of Business Research, vol. 66, no. 9, pp. 1279-1284, 2013.

[88] Q. Zhao, C. Der Chen, J. L. Wang, and P. C. Chen, Determinants of backers' funding intention in crowdfunding: Social exchange theory and regulatory focus, Telematics and Informatics, vol. 34, no. 1, pp. 370-384, 2017. 